\title{
CLTC/TFE3 Fusion Gene
}

National Cancer Institute

\section{Source}

National Cancer Institute. CLTC/TFE3 Fusion Gene. NCI Thesaurus. Code C99194.

A fusion gene that results from a chromosomal translocation $t(X ; 17)(p 11.2 ; q 23)$ which

fuses the first 17 exons of the CLTC gene with the portion of the TFE3 gene that

encodes the C-terminal portion of the protein. This fusion is associated one case of renal cell carcinoma. 